\title{
"The impact of the national tourism system on the economic growth in Ukraine"
}

Anatoliy Mazaraki $\mathbb{D}$ http://orcid.org/0000-0001-5283-8444
$\mathbb{R}$ http://www.researcherid.com/rid/E-2399-2018
Margaryta Boiko $\mathbb{D}$ http://orcid.org/0000-0003-0249-1432
$\mathbb{R}$ http://www.researcherid.com/rid/N-3073-2016
Alla Okhrimenko $\mathbb{D}$ http://orcid.org/0000-0003-0405-3081
R https://publons.com/researcher/2216029/alla-ao-okhrimenko/
Svitlana Melnychenko $\mathbb{D}$ http://orcid.org/0000-0002-5162-6324
R https://publons.com/researcher/2212404/svitlana-melnychenko/
Tetiana Zubko (D http://orcid.org/0000-0002-8950-1797
R http://www.researcherid.com/rid/M-8634-2016

Anatoliy Mazaraki, Margaryta Boiko, Alla Okhrimenko, Svitlana Melnychenko and ARTICLE INFO Tetiana Zubko (2019). The impact of the national tourism system on the economic growth in Ukraine. Problems and Perspectives in Management, 17(4), 93-103. doi:10.21511/ppm.17(4).2019.08

DOI http://dx.doi.org/10.21511/ppm.17(4).2019.08

RELEASED ON Friday, 15 November 2019

RECEIVED ON Wednesday, 11 September 2019

ACCEPTED ON Wednesday, 06 November 2019

(cc) EY

LICENSE

This work is licensed under a Creative Commons Attribution 4.0 International License

JOURNAL

"Problems and Perspectives in Management"

ISSN PRINT $1727-7051$

ISSN ONLINE $1810-5467$

PUBLISHER

LLC "Consulting Publishing Company "Business Perspectives"

FOUNDER

LLC "Consulting Publishing Company "Business Perspectives"

NUMBER OF REFERENCES

49
NUMBER OF FIGURES

3
NUMBER OF TABLES

2

(C) The author(s) 2022. This publication is an open access article. 


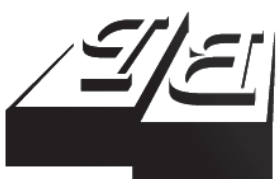

BUSINESS PERSPECTIVES

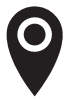

LLC "CPC "Business Perspectives" Hryhorii Skovoroda lane, 10, Sumy, 40022, Ukraine

www.businessperspectives.org

Received on: $11^{\text {th }}$ of September, 2019 Accepted on: $6^{\text {th }}$ of November, 2019

(C) Anatoliy Mazaraki, Margaryta Boiko, Alla Okhrimenko, Svitlana Melnychenko, Tetiana Zubko, 2019

Anatoliy Mazaraki, Doctor of Economics, Professor, Kyiv National University of Trade and Economics, Ukraine.

Margaryta Boiko, Doctor of Economics, Professor, Kyiv National University of Trade and Economics, Ukraine.

Alla Okhrimenko, Ph.D. in Economics, Associate Professor, Kyiv National University of Trade and Economics, Ukraine.

Svitlana Melnychenko, Doctor of Economics, Professor, Kyiv National University of Trade and Economics, Ukraine.

Tetiana Zubko, Ph.D. in Economics, Associate Professor, Kyiv National University of Trade and Economics, Ukraine.

\section{(ㄷ) (i)}

This is an Open Access article, distributed under the terms of the Creative Commons Attribution 4.0 International license, which permits unrestricted re-use, distribution, and reproduction in any medium, provided the original work is properly cited.
Anatoliy Mazaraki (Ukraine), Margaryta Boiko (Ukraine), Alla Okhrimenko (Ukraine), Svitlana Melnychenko (Ukraine), Tetiana Zubko (Ukraine)

\section{THE IMPACT OF THE NATIONAL TOURISM SYSTEM ON THE ECONOMIC GROWTH IN UKRAINE}

\begin{abstract}
The paper aims at analyzing the impact of tourism on the economic growth in Ukraine considering its global significance and dynamic development. Tourism should be considered not as a separate phenomenon, but as a complex socio-economic-ecological system, i.e. the national tourism system (NTS). The study attempts to reveal the nature and determinants of the national tourism system impact on economic growth, and also empirically substantiates this in the Ukrainian context. Since the economic decisions require a huge amount of information and different models, a multivariate least square model has been proposed to determine the causal links between NTS and economic growth. The paper also presents the economic parameters such as Ukrainian GDP as a dependent variable, volume of domestic tourism consumption, income from international passenger carriage, international tourism expenditures in the country, the volume of services provided in temporary accommodation and catering establishments, and country's income from NTS as independent variables. The paper is based on the 2000-2017 statistical data. It concludes that the increase of total NTS contribution to GDP is influenced by all considered factors except the international tourism expenditures in the country. A proposed econometric factor analysis model can be used as a tool to analyze and forecast the socio-economic NTS processes. The hypothesis of the NTS's impact on economic growth is substantiated.
\end{abstract}

\section{Keywords tourism, tourist industry, economic growth, GDP}

JEL Classification L83, P47

\section{INTRODUCTION}

Tourism, as a component of the global economy, shows dynamic growth. According to the World Tourism Organization, in 2018, international tourist arrivals grew $5 \%$ to reach the 1.4 billion. At the same time, earnings generated by tourism have grown to USD 1.7 trillion (UNWTO, 2019). The travel and tourism industry generates $10.4 \%$ of the world GDP and supports 319 million working places (World Travel and Tourism Council, 2019). It should be also noted that over the long term, the income growth from international tourism exceeds the global GDP growth. This fact highlights the dynamic development and ability of tourism to be a catalyst for various socio-economic processes.

The need to comprehensively reflect the socio-ecological and economic nature of tourism, Okhrimenko (2017), Boiko, Bosovska, Vedmid, Bovsh, and Okhrimenko (2018), Mazaraki, Boiko, Bosovska, Vedmid, and Okhrimenko (2018) substantiated conceptual bases of functioning and development of the national tourism system (NTS). The authors proposed to consider NTS as a component of the national economic system, a spatially localized set of socio-economic, functional, sectorial, institutional and information subsystems that form produc- 
tion, sales and consumption of the tourist product based on targeted interaction. These basic characteristics of the NTS reflect its polystructural nature and confirm its deeper epistemological understanding.

Continuing their research into the NTS functioning and development, the authors point to the need for evaluating its impact on the national economy, in particular on its economic growth. The following arguments are put forward: first, the importance of research on the NTS impact on economic growth manifests itself through the institutional aspect: “...tourism's economic impacts are therefore an important consideration in state, regional and community planning and economic development; economic impacts are also important factors in marketing and management decisions" (Stynes, 1997); second, in consumer-based and marketing terms: "...economic impact studies are very much beneficial because they illustrate the benefits of travel and tourism" (Kuman \& Hussain, 2014); third, in terms of improved macroeconomic parameters and destination employment, since "... for a growth of economy, tourism is an exceptional facilitator, that is why it is a vital part in macroeconomic level; this business is imperative to force labor and is essential cause of government's revenues" (Agaraj \& Murati, 2009); fourth, via the stimulating aspect of other socio-economic systems: "...tourism is part of the economic system; it plays an important role in the economy due to the multiplier effect (encouraging other economic activities)" (Trebicka, 2016, p. 17). In this context, it should also be noted that growth theories explain the factors that determine the rate of economic growth in a country. On the other hand, growth theories explain the reasons for differences in income and growth rates among countries (Soylu, Çakmak, \& Okur, 2018, p. 95).

Given the cross-sectoral nature of the NTS functioning, which accumulates different types of economic activity, resources, and differentiated consequences of its functioning (in time, by regions and countries, by types and forms of tourism), the analysis of its impact on the economic growth will contribute to a real assessment of the NTS contribution to GDP, a factor analysis of determinants, and NTS monitoring in time and space. Besides, for a tourism-based economy to sustain itself in local communities, the residents must be willing partners in the process; their attitudes toward tourism and perceptions of its impact on community life must be continually assessed (Allen, Long, Perdue, \& Kieselbach, 1988).

The findings of many studies on the impact of tourism on economic growth (Jacint \& Cantavella-Jorda, 2002; Fawaz, Rahnama, \& Stout, 2014; Gwenure \& Odhiambo, 2017) indicate that the causal relationship between tourism and economic growth differs from country to country.

Therefore, summarizing the above arguments, it is necessary to point out the relevance of studying the NTS's impact on the economic growth in Ukraine, which has a significant tourist potential as a macro destination.

\section{LITERATURE REVIEW}

Scientific systematic studies on tourism benefits and its impact on the economy were in the 70's and 80 's of the $20^{\text {th }}$ century. They substantiate the specificity of tourism as an economic and social activity and a catalyst for dynamic change in other areas (Sadler \& Archer, 1975; Duffield, 1982; Archer, 1982). After a while, tourism studies began to use Input-Output Models (Fletcher, 1989; Heng \& Low, 1990), Tourism Multiplier (Archer, 1982; Hughes, 1994; Frechtling \&
Horvath, 1999; Hojo, 2002), Social Accounting Matrix - SAM (Pyatt \& Round, 1985; Croes \& Rivera, 2015), Tourism Satellite Account TSA 2008 (UNWTO, 2001, 2010), Computable General Equilibrium - CGE (Burfisher, 2011; Dwyer, 2015) and others.

Most of these models require detailed and timely statistical information, which is a problem for Ukraine. Modern and recognized statistical tools for assessing the economic importance of tourism include International 
Recommendations for Tourism Statistics (World Tourism Organization, 2010a). However, only since 2021 in Ukraine, according to the Order of the State Statistics Service of Ukraine (2017), it is envisaged to introduce the tables of the satellite tourism account in the national statistical reports in accordance with the Methodological provisions for compiling a subsidiary (satellite) tourism account in Ukraine (2017) with a threeyear frequency.

Stynes $(1997,1999)$ attempted to define the key concepts and explain the basic methods for estimating the economic impacts of tourism and proved that income or value added are the best measures of the economic gain to the region from tourism (Stynes, 1997, p. 16). That is, the emphasis is not only placed on the assessment of the multiplier effect in tourism, but also on direct indicators of the territory development.

Many scientists, while analyzing the impact of tourism on the economic growth in different countries (S. Hadad, Y. Hadad, Malul, \& Rosenboim, 2012; Bulin, Miru, \& Gheorghe, 2014; Kamac1 \& Oğan, 2014; Herget, Petrů, \& Abrhám, 2015; Saglam \& Egeli, 2018), use methods, whose information background is based on the generally accepted statistics of the World Tourism Organization (UNWTO), the World Travel \& Tourism Council (WTTC), the World Bank, and the World Economic Forum (WEF). Thus, the research by Soysal-Kurt (2017) and Ilić and Petrevska (2018), who explored the impact of NTS on economic growth, shows that such studies can also be performed using:

- indicative (structural) analysis (one-dimensional in terms of purpose and content);

- parametric methods (where the operational function is determined in advance, and changes that may accidentally be affected are taken into account: factor analysis, regression analysis);

- non-parametric methods (they are flexible; the analysis is performed without previously determining the operational function, using linear programming: DEA method, artificial intelligence network, etc.).
Using the above methods, studies emerge, in which the tourism development indicators are analyzed by country or group of countries with the focus on the basic resultant direct indicators of the functioning and development of tourism systems, namely the volume of tourist flows, income, expenses, and profits in different lags.

Gwenhure and Odhiambo (2017) carefully analyzed international literature for the period 2002-2017 on the tourism impact and the economic growth; they also reviewed some empirical studies on the causal relationship between tourism sector development and economic growth based on a time series data analysis, panel/cross-sectional data analysis and input/ output analysis. The analysis of scientific works suggests that there are currently scientific works reflecting the direct impact of tourism on economic growth in different countries and regions. One of the recent works is that by Van der Schyff, Meyer, and Ferreira (2019) that follows a quantitative research approach by investigating the relationship between tourism and economic growth from 2005 to 2017 in South Africa. These relationships were analyzed using the Johansen cointegration and Vector Error Correction Models. The results indicate there is a long-run relationship between tourism and both economic growth and development. Besides, Rasul, Amanj Ahmad, and Saed (2019) proved the economic benefits of tourism and predicted its positive growth rate in the Kurdistan Region of Iraq. Thus, the results point to a long-term relationship between tourism and economic growth.

\section{RESEARCH PURPOSE}

The purpose of the article is to reveal the essence and determinants of the national tourism system's influence on the economic growth and justify it empirically using the Ukrainian economy as an example.

\section{RESEARCH METHOD}

The synthesis of Ukrainian and international studies on justifying indicators to assess the 
climate of the national tourism system and its impact on the economic growth of Ukraine made the basis for this article. This issue has been studied using theoretical generalization, analysis and synthesis, and prediction. The main focus is on the application of econometric models. This is because most decisions on managing complex economic systems, in particular, resource allocation, the choice of the best scenario, the study of market conditions, planning, and forecasting, require prior econometric modeling of a specific process or its components. The modeling importance is due to the main feature of the model, namely, a simplified representation of the essential characteristics of a real object or situation. Since econometric methods allow constructing models that accurately and fully reflect the various aspects of the operation and development of research objects, the paper focuses on parametric techniques.

In this context, Stynes (1997, p. 16) states that multiplier effects are not nearly as important in most cases, as their use in tourism would suggest and multipliers tend to introduce complexities that most users of the results do not fully understand, so the current study will focus on assessing the direct effects of the NTS.

To determine the cause-effect relationship between NTS and economic growth, a multifactor model based on the least square method was constructed, which made it possible to use different values. In the modeling process, the following conditions are met: the mathematical expectation of residuals is zero; the values of the residue vector are independent of each other and have a constant dispersion; independent model variables do not relate to model residuals; independent variable models form a linear independent vector system.

Accordingly, a functional multifactor relationship among economic parameters has been constructed, one of which is a dependent variable (the contribution of NTS to the GDP of Ukraine), and the other are independent variables (the volume of domestic tourism consumption, revenues from international passenger carriage, international tourism expenditures in the country, the volume of services provided in temporary accommodation and catering establishments, the country's income from NTS). The sequence of studying results from the logical construction of any econometric model: 1) specifying the study purpose; 2) constructing a system of indicators and logical selection of factors that most influence them; 3) choosing the form of the indicator interrelationship; 4) selecting output data (2000-2017 statistics were used according to the World Tourism Organization (UNWTO), the World Travel \& Tourism Council (WTTC), and the World Bank)); 5) direct construction of the econometric model; 6) inspecting the model quality, including the economic process adequacy; and 7) using the model.

\section{RESULTS}

Economic growth is the first macroeconomic goal of any economy; it implies a steady increase in the total volume of goods and services expressed in GDP over a given period compared to the previous one (Fourie \& Burger, 2015, p. 12). Therefore, there is an axiom that economic growth is interrelated with GDP. Barro (2001) pays attention to the fact that economic growth refers to the growth of aggregate productivity, traditionally measured in GDP. Moreover, a steadily growing national economy increases the choices available to residents and institutions that lead to improving the quality of life for all and is a primary policy objective of most national governments (Frechtling, 2013, p. 1), so communities, therefore, need to understand the relative importance of tourism to their region, including tourism's contribution to economic activity in the area (Stynes, 1997).

Gwenhure and Odhiambo (2017, p. 41), while studying the scientific literature on the impact of tourism on economic growth, focus on the causal relationship between the two. The researchers highlight four main views on the factor relationship between tourism and economic growth: 1) the unidirectional impact of tourism on economic growth - the hypothesis of tourism resulting in growth; 2) the unidirectional impact of economic growth on tourism (a tourism-oriented growth hypothesis); 3) there is a bidirectional factor relationship between 

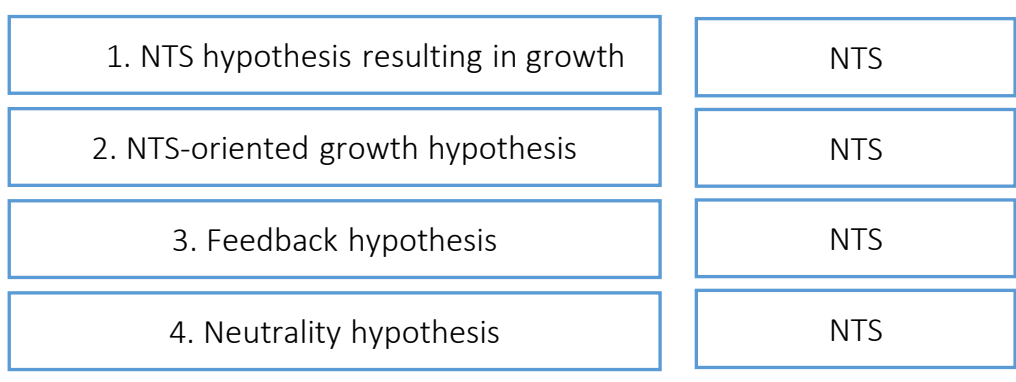

Figure 1. The semantics of hypotheses on the NTS an economic growth correlation

tourism and economic growth - the feedback hypothesis; and 4) the neutrality hypothesis, where neither of the variables affects the other (see Figure 1).

Given the hypothesis semantics (see Figure 1) on the NTS and economic growth interaction, it would appropriate to prove the first hypothesis. Van der Schyff et al. (2019, p. 170), while analyzing the macroeconomic studies of Dornbusch, Fisher, and Startz (2014, p. 63), conclude that endogenous growth and neoclassical growth theories relate to tourism in the sense that investing in tourism technology and skills can increase its contribution to GDP, i.e., the relationship between tourism and economic growth comes from the growth hypothesis generated by tourism.

The NTS economic growth is an upward trend of its contribution to GDP; it is not necessary to increase the real contribution annually, but only to focus on growth, not in the short term, but in the long term and taking into account not nominal, but real indicators.

It was further found that the complexity of determining the NTS contribution to the Ukrainian economy relates to identifying the implicit boundary between tourists and locals; involving a significant amount of ancillary and ensuring economic activities in the NTS; lack of consideration of some significant volumes of tourist groups (in particular, domestic, unorganized, tourists (use exchange accommodation), partially sightseers, etc.) in statistical surveys/results/indices; spontaneous transition to the category of business tourists, business- men within the country. These aspects form the problem that has not yet been solved, namely, the real definition of NTS's contribution to GDP, employment, investment, etc.

As noted above, the purpose of this study is to specify the impact of NTS on economic growth represented by GDP, which is a dependent variable. Given that the NTS is a system with various links between the elements of the economy of a particular country and the world economy, multiple aspects of its functioning in spatial terms were considered while choosing independent variables: domestic tourism, outbound tourism, and inbound tourism. Accordingly, the independent variables were selected: domestic tourism consumption, revenues from international passenger carriage, international tourism expenditures in the country, the volume of services provided in establishments for temporary accommodation and catering, country's income from the NTS. On this basis, a multifactor model is constructed, which determines the linear relationship between the factor and the resulting variables.

$$
Y=a_{0}+a_{1} X_{1}+\ldots+a_{3} X_{3},
$$

where $Y$ - total NTS contribution to GDP, UAH billion; $x_{1}$ - domestic tourism consumption, $\mathrm{UAH}$ billion; $\mathrm{x}_{2}$ - revenues from passenger carriage (expenses of foreign visitors in the national economy), UAH billion; $x_{3}$ - country's income from NTS, UAH billion; $x_{4}$ - international tourism expenditures in the country, UAH billion; $\mathrm{x}_{5}$ - the volume of services provided in temporary accommodation and catering establishments, UAH billion (see Figure 2). 
Thus, the study considers the econometric model of the dependence of domestic tourism consumption in Ukraine on the five factors identified, $t \in$ [2000, 2017]:

$$
\begin{aligned}
& Y(t)=a_{0}+a_{1} x_{1}(t)+a_{2} x_{2}(t)+ \\
& +a_{3} x_{3}(t)+a_{4} x_{4}(t)+a 5 \times 5(t)+\varepsilon(t), \\
& t \in[2000,2017] .
\end{aligned}
$$

where $a_{0}, a_{1}, a_{2}, a_{3}, a_{4}, a_{5}$ are parameters to be estimated; $\varepsilon(t)$ is an unobserved random value.

Let's apply the LINEAR built-in function (see Figure 2).

The regression equation is as follows:

$$
\begin{aligned}
& \hat{Y}(t)=1.92+0.747 x_{1}+1.302 x_{2}+ \\
& +2.227 x_{3}-1.457 x_{4}+0.666 x_{5},
\end{aligned}
$$

The determination coefficient $R^{2}=0.999$ indicates a close relationship between these factors and the volume of income from the Ukrainian NTS. The model test for validity using the F-criterion showed that the model is reliable $\left(F_{\text {calc }}=1720.21\right.$ $\left.>F_{\mathrm{tab}}=3.18\right)$.
The analysis of the regression dependence parameters shows that international tourism expenditures in the country and the income from international passenger transportation exert the most significant influence on the amount of revenues from NTS.

To check the significance of the correlation coefficient $R$, the Student's t-test has been calculated:

$t_{\alpha}=\frac{R \sqrt{n-m}}{\sqrt{1-R^{2}}}=\frac{\sqrt{0.999(18-4)}}{\sqrt{1-0.999}}=4.001$,

Using statistical tables at the significance level of $\alpha$ $=0.01$ and degrees of freedom 14, $t_{\text {tab }}=2.624$ has been chosen.

Since $t>t_{t a b}$, one can argue for the correlation coefficient significance.

To evaluate the significance of estimates of the multiple regression model parameters, the $t$-criterion is calculated. To obtain the calculated values of $t$, it is

\begin{tabular}{|c|c|c|c|c|c|c|c|c|c|c|c|c|c|c|c|}
\hline & • $\quad \vdots$ & $\checkmark$ & $\{=\operatorname{LIN}$ & (E5:E22;F & $22 ; 1 ; 1)\}$ & & & & & & & & & & \\
\hline \multirow[t]{23}{*}{ c } & D & E & $\mathrm{F}$ & G & $\mathrm{H}$ & 1 & $\mathrm{~J}$ & K & L & M & $\mathrm{N}$ & 0 & $P$ & Q & $R$ \\
\hline & & & & & & & & & & & & & & & \\
\hline & & & & & & & & & & & & & & & \\
\hline & & & & & & & & & & & & & & & \\
\hline & & $\mathrm{Y}$ & $\mathrm{X} 1$ & $\mathrm{x} 2$ & $\mathrm{X} 3$ & $\mathrm{X} 4$ & $\begin{array}{ll}\mathrm{x} 5 \\
\end{array}$ & & & & & & & & \\
\hline & 2000 & 12,200 & 10,300 & 0,919 & 2,143 & 3,000 & 0,670 & & & & & & & & \\
\hline & 2001 & 14,300 & 12,200 & 0,999 & 3,077 & 3,900 & 0,698 & & & & & & & & \\
\hline & 2002 & 15,700 & 13,200 & 1,135 & 4,200 & 5,100 & 0,790 & & & & & & & & \\
\hline & 2003 & 18,800 & 16,600 & 1,434 & 4,984 & 6,200 & 0,881 & & & & & & & & \\
\hline & 2004 & 31,600 & 27,400 & 1,974 & 13,619 & 14,900 & 1,120 & & & 0,666 & $-1,457$ & 2,227 & 1,302 & 0,747 & 1,920 \\
\hline & 2005 & 38,300 & 31,600 & 2,135 & 16,000 & 17,400 & 1,633 & & & 0,317 & 0,825 & 0,835 & 0,711 & 0,168 & 0,987 \\
\hline & 2006 & 45,800 & 37,100 & 2,692 & 17,599 & 19,400 & 2,199 & & & 0,999 & 1,867 & \#n.a. & \#n.a. & \#n.a. & \#n.a. \\
\hline & 2007 & 59,500 & 47,100 & 3,651 & 23,215 & 25,700 & 2,965 & & & 1720,210 & 12,000 & \#n.a. & \#n.a. & \#n.a. & \#n.a. \\
\hline & 2008 & 76,100 & 61,700 & 5,199 & 31,436 & 33,900 & 1,633 & & & 29982,925 & 41,832 & \#n.a. & \#n.a. & \#n.a. & \#n.a. \\
\hline & 2009 & 76,500 & 61,400 & 6,022 & 27,857 & 32,500 & 3,408 & & & & & & & & \\
\hline & 2010 & 82,200 & 70,300 & 7,210 & 30,077 & 35,800 & 4,248 & & & & & & & & \\
\hline & 2011 & 93,100 & 83,800 & 8,840 & 34,137 & 41,200 & 5,044 & & & & & & & & \\
\hline & 2012 & 105,600 & 93,400 & 9,157 & 38,688 & 45,800 & 5,601 & & & & & & & & \\
\hline & 2013 & 111,300 & 95,800 & 6,784 & 40,664 & 45,500 & 6,192 & & & & & & & & \\
\hline & 2014 & 87,400 & 74,200 & 7,752 & 19,167 & 23,500 & 17,842 & & & & & & & & \\
\hline & 2015 & 106,900 & 93,800 & 12,679 & 23,653 & 30,400 & 15,267 & & & & & & & & \\
\hline & 2016 & 129,000 & 112,100 & 16,480 & 27,543 & 37,500 & 19,572 & & & & & & & & \\
\hline & 2017 & 147,200 & 130,400 & 19,646 & 33,568 & 45,700 & 23,483 & & & & & & & & \\
\hline & & & & & & & & & & & & & & & \\
\hline
\end{tabular}
necessary to divide the first line numbers into the corresponding values in the second line (Figure 1) and evaluate the results using the module:

Source: Developed by the authors.

Figure 2. Parameters calculation for the interaction between the resulting indicator functional and the independent model variables 


$$
t_{j}=\frac{\left|\hat{a}_{j}\right|}{\sigma_{\hat{a}_{j}}},
$$

Thus, $t_{0}=1.946, t_{1}=4.458, t_{2}=1.831, t_{3}=2.666, t_{4}$ $=1.766, t_{5}=2.1$.

The $t$-critical value is found from the $t$-statistics for $\alpha=0.05$ and $n-m=18-4=14$ degrees of freedom; $t$-critical for the two-sided test is 1.761 . All model parameters are statistically significant with the probability of 0.99 , i.e., the correct form of influence of these parameters is chosen. The constructed model verification is given in Table 1 and Figure 3.

Table 1. Verification of the model constructed

Source: Developed by the authors.

\begin{tabular}{c|c|c|c}
\hline Years & Actual value & Calculated value & Deviation \\
\hline 2000 & 12.2 & 11.66078 & 0.539 \\
\hline 2001 & 14.3 & 13.97 & 0.330 \\
\hline 2002 & 15.7 & 15.70881 & -0.009 \\
\hline 2003 & 18.8 & 18.83978 & -0.040 \\
\hline 2004 & 31.6 & 34.3262 & -2.726 \\
\hline 2005 & 38.3 & 39.67513 & -1.375 \\
\hline 2006 & 45.8 & 45.53318 & 0.267 \\
\hline 2007 & 59.5 & 58.09028 & 1.410 \\
\hline 2008 & 76.1 & 76.48715 & -0.387 \\
\hline 2009 & 76.5 & 72.58656 & 3.913 \\
\hline 2010 & 82.2 & 81.47773 & 0.722 \\
\hline 2011 & 93.1 & 95.39205 & -2.292 \\
\hline 2012 & 105.6 & 106.7773 & -1.177 \\
\hline 2013 & 111.3 & 110.711 & 0.589 \\
\hline 2014 & 87.4 & 87.77596 & -0.376 \\
\hline 2015 & 106.9 & 107.0584 & -0.158 \\
\hline 2016 & 129 & 126.8672 & 2.133 \\
\hline 2017 & 147.2 & 148.7373 & -1.537 \\
\hline & & & \\
\hline
\end{tabular}

$$
D W=78.24617 / 41.82873=1.871
$$

The small sample size does not allow for a clear conclusion. Let's calculate the von Neumann criterion:

$$
\begin{aligned}
& Q=\frac{n}{n-1} \cdot D W, \\
& Q_{\text {actual }}=\frac{18}{17} \cdot 1.871=1.981 .
\end{aligned}
$$

Given that the number of observations is 18 and the significance level is $\alpha=0.001, Q_{\text {tab }}=0.0349$. Since $Q_{\text {actual }}>Q_{\text {tab }}$, there is no residual correlation, so the model is well-formed.

The estimated equation makes it possible to conclude that the increase in the total contribution of NTS to GDP is influenced by the factors specified, Source: Developed by the authors.

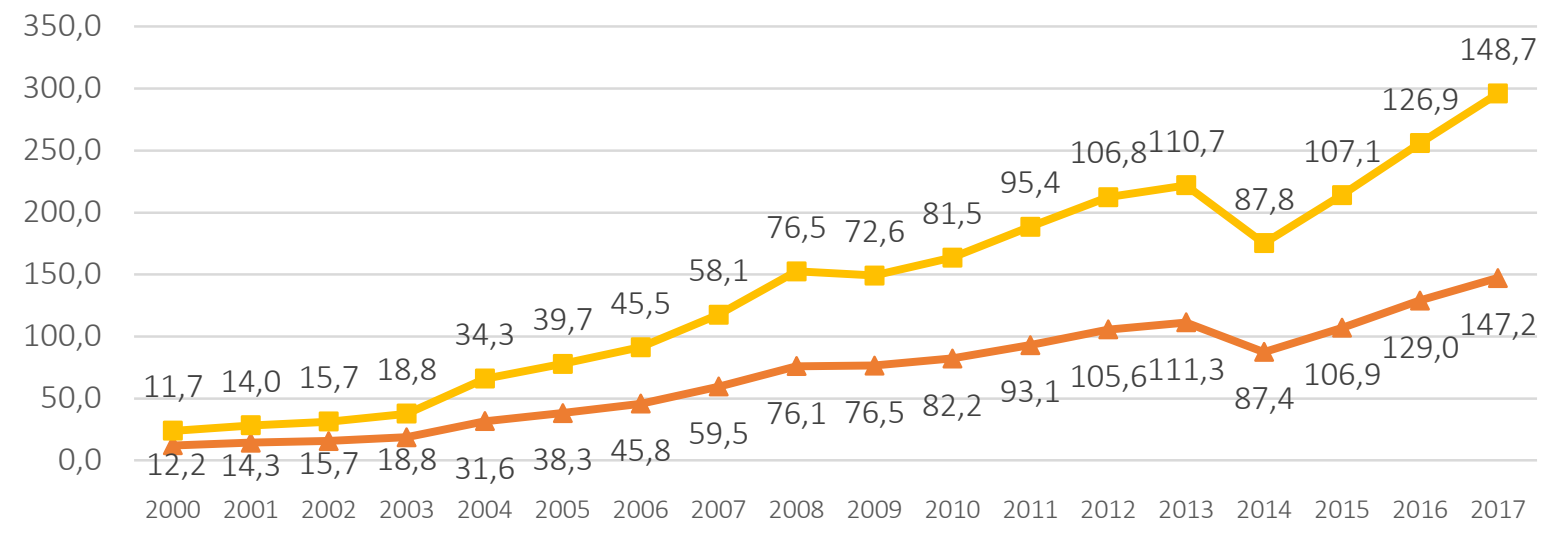

- Actual value $\quad-$ Calculated value

Figure 3. The actual and model-based dynamics of change in the dependent feature 
Table 2. Calculated data for determining the Durbin-Watson criterion

Source: Developed by the authors.

\begin{tabular}{|c|c|c|c|c|c|c|}
\hline $\mathbf{i}$ & $\mathbf{Y}$ & $Y^{*}$ & $\mathbf{U}_{\mathrm{t}}=\mathrm{Y}-\mathrm{Y}^{*}$ & $\mathbf{U}^{2}$ & $U_{t}-U_{t-1}$ & $\left(U_{t}-U_{t-1}\right)^{2}$ \\
\hline 1 & 12.2 & 11.66078 & 0.539 & 0.290521 & - & - \\
\hline 2 & 14.3 & 13.97 & 0.330 & 0.1089 & -0.209 & 0.043681 \\
\hline 3 & 15.7 & 15.70881 & -0.009 & 0.000081 & -0.339 & 0.114921 \\
\hline 4 & 18.8 & 18.83978 & -0.040 & 0.0016 & -0.031 & 0.000961 \\
\hline 5 & 31.6 & 34.3262 & -2.726 & 7.431076 & -2.686 & 7.214596 \\
\hline 6 & 38.3 & 39.67513 & -1.375 & 1.890625 & 1.351 & 1.825201 \\
\hline 7 & 45.8 & 45.53318 & 0.267 & 0.071289 & 1.642 & 2.696164 \\
\hline 8 & 59.5 & 58.09028 & 1.410 & 1.9881 & 1.143 & 1.306449 \\
\hline 9 & 76.1 & 76.48715 & -0.387 & 0.149769 & -1.797 & 3.229209 \\
\hline 10 & 76.5 & 72.58656 & 3.913 & 15.31157 & 4.3 & 18.49 \\
\hline 11 & 82.2 & 81.47773 & 0.722 & 0.521284 & -3.191 & 10.182481 \\
\hline 12 & 93.1 & 95.39205 & -2.292 & 5.253264 & -3.014 & 9.084196 \\
\hline 13 & 105.6 & 106.7773 & -1.177 & 1.385329 & 1.115 & 1.243225 \\
\hline 14 & 111.3 & 110.711 & 0.589 & 0.346921 & 1.766 & 3.118756 \\
\hline 15 & 87.4 & 87.77596 & -0.376 & 0.141376 & -0.965 & 0.931225 \\
\hline 16 & 106.9 & 107.0584 & -0.158 & 0.024964 & 0.218 & 0.047524 \\
\hline 17 & 129 & 126.8672 & 2.133 & 4.549689 & 2.291 & 5.248681 \\
\hline 18 & 147.2 & 148.7373 & -1.537 & 2.362369 & -3.67 & 13.4689 \\
\hline$\Sigma$ & $1,251.5$ & $1,251.675$ & - & 41.82873 & - & 78.24617 \\
\hline
\end{tabular}

except for international tourism expenditures in the country. Thus, with an increase in domestic tourism consumption by UAH 1 billion, the contribution of NTS to GDP will grow by UAH 0.747 billion. With an increase in revenues from international passenger transportation by UAH 1 billion, the factor attribute will increase by $\mathrm{UAH}$ 1.302 billion. With the rise in the country's income from NTS by UAH 1 billion, the contribution of NTS to GDP will grow by UAH 2.227 billion. As the volume of services provided in temporary accommodation and catering estab- lishments increases by UAH 1 billion, the resultant factor will grow by UAH 0.666 billion. The negative value of the parameter of international tourism expenditures in the country on the NTS volume is because this factor is partially duplicated in two model factors: $x_{2}$ means revenues from international passenger transportation (expenses of foreign visitors in the national economy) and $\mathrm{x}_{1}$ is the volume of domestic tourism consumption. Therefore, the hypothesis about the NTS development resulting in economic growth has been proved.

\section{CONCLUSION}

The tourism market globalization not only determines the unique mega-environment for the NTS, but also high competition. Globalization, on one hand, is a source and a stimulator of competition, providing new opportunities for development, and on the other hand, it causes economic asymmetries that are not homogeneous. It should be noted that the aggregated NTS can obtain investment attractiveness provided that the external economic effects of the NTS are specified in a transparent manner.

It should be noted that it is difficult to determine the NTS impact on economic growth because tourist expenditures have a cascading effect on the local economy (Tkachenko, 2006, p. 144; Tkachenko, 2008, p. 180). The use of economic and mathematical modeling has convincingly demonstrated that in order to fully 
assess the economic impact of the NTS on economic growth, it is necessary to investigate the additional tourist spending in a destination that contributes to income generation, employment and other benefits to the host economy. Accordingly, the NTS's impact assessment is based on the calculated and analytical indicators (NTS contribution to GDP, domestic tourism consumption, revenues from international travel, international tourism expenditures in the country, the volume of services provided in establishments for temporary accommodation and catering, the country's NTS profit) that reveal the process dynamics. In this case, it is also essential to understand the indirect impact of tourism, which reflects the cross-sectorial links in creating and selling tourism products and determines the priority of investing in development of promising destinations at both regional and national levels.

\section{ACKNOWLEDGMENT}

This article reflects the authors' results in studies conducted in 2017-2020 at the Kyiv National University of Trade and Economics at the of the Ministry of Education and Science of Ukraine request (Integration of the Ukrainian Tourism System into the World Services Market, state registration number 0117U000503; Formation of the National Brand of Ukraine in the International Environment, state registration number 0118U000127).

\section{REFERENCES}

1. Agaraj, X., \& Murati, M. (2009). Tourism an Important Sector of Economy Development. Retrieved from http://www.utgjiu.ro/revista/ ec/pdf/2009-01/6_XHILIOLA_ AGARAJ.pdf

2. Allen, L. R., Long, P. T., Perdue, R. R., \& Kieselbach, S. (1988). The Impact of Tourism Development on Residents' Perceptions of Community Life. Journal of Travel Research, 27(1), 16-21. https://doi. org/10.1177/004728758802700104

3. Archer, B. H. (1982). The value of multipliers and their policy implications. Tourism Management, 3(4), 236-241. https://doi. org/10.1016/0261-5177(82)90044-9

4. Barro, R. (2001). Determinants of economic growth. Cambridge: Mass. MIT Press. Retrieved from https://mitpress.mit.edu/books/ determinants-economic-growth

5. Boiko, M., Bosovska, M., Vedmid, N., Bovsh, L., \& Okhrimenko, A. (2018). Investment attractiveness of the Ukrainian tourism system. Investment Management and Financial Innovations, 15(4), 193-209. https://doi.org/10.21511/ imfi.15(4).2018.16

6. Bulin, D., Miru, N., \& Gheorghe, G. (2014). The impact of tourism industry in the economy. The case of black sea region countries. Knowledge Horizons, Economics, 6(2), 74-79. Retrieved from https://econpapers.repec.org/ article/khejournl/v_3a6_3ay_3a20 14_3ai_3a2_3ap_3a74-79.htm

7. Burfisher, M. (2011). Introduction to Computable General Equilibrium Models. Cambridge: Cambridge University Press. https://doi. org/10.1017/CBO9780511975004

8. Croes, R., \& Rivera, M. (2015). Tourism potential to benefit the poor: a social accounting matrix model applied to Ecuador. Tourism Economics. http://dx.doi. org/10.5367/te.2015.0495

9. Dornbusch, R., Fisher, S., \& Startz, R. (2014). Macroeconomics (12th ed). Singapore: McGraw Hill Education.

10. Duffield, B. S. (1982). Tourism: the measurement of economic and social impact. Tourism Management, 3(4), 248-255. https://doi. org/10.1016/0261-5177(82)90046-2

11. Dwyer, L. (2015). Computable general equilibrium modelling for tourism policy: Inputs and Outputs. (UNWTO Statistics and TSA Issue Paper Series STSA/IP/2015/02). Retrieved from http://cf.cdn. unwto.org/sites/all/files/docpdf/ ipcomputablepaper.pdf

12. Fawaz, F., Rahnama, M., \& Stout, B. (2014). An empirical refinement of the relationship between tourism and economic growth. Anatolia, 25(3), 352-363. https:// doi.org/10.1080/13032917.2013. 876434

13. Fletcher, J. E. (1989). Input-output analysis and tourism impact studies. Annals of Tourism Research, 16(4), 514-529. Retrieved from https://www.academia. edu/1319012/Input-output_analysis_and_tourism_impact_studies

14. Fourie, F., \& Burger, Ph. (2015). How to think and reason in macroeconomics. Cape Town, South Africa, Juta. Retrieved from https:// juta.co.za/catalogue/?q=ebooks/ how $\% 20$ to\%20think\%20and\%20 reason $\% 20$ in $\% 20$ macroeconomics $\% 203 \mathrm{e} \% 20$ ebook

15. Frechtling, D. (2013). The Economic Impact of Tourism: Overview and Examples of Macroeconomic Analysis (UNWTO Statistics and TSA Issue Paper Series STSA/ IP/2013/03). Retrieved from http://cf.cdn.unwto.org/sites/ all/files/IP_Economic_Impact_ EN.pdf 
16. Frechtling, D. C., \& Horvath, E. (1999). Estimating the Multiplier Effects of Tourism Expenditures on a Local Economy through a Regional Input-Output Model. Journal of Travel Research, 37(4), 324-332. https://doi. org/10.1177/004728759903700402

17. Gwenhure, Y., \& Odhiambo, N. M. (2017). Tourism and economic growth: A review of international literature. Tourism, 65(1), 33-44. Retrieved from https://hrcak.srce. $\mathrm{hr} / 178621$

18. Hadad, S., Hadad, Y., Malul, M., \& Rosenboim, M. (2012). The economic efficiency of the tourism industry: A global comparison. Tourism Economics, 18(5), 931940. https://doi.org/10.5367/ te.2012.0165

19. Heng, M. T., \& Low, L. (1990). Economic impact of tourism in Singapore. Annals of Tourism Research, 17(2), 246-269. Retrieved from http://scholarbank.nus.edu. sg/handle/10635/19379

20. Herget, J., Petrů, Z., \& Abrhám, J. (2015). City branding and its economic impacts on tourism. Economics and Sociology, 8(1), 119-126. https:// doi.org/10.14254/2071789X.2015/8-1/9

21. Hojo, Y. (2002). The Expansions of the Essays on Tourism Multiplier Model. The Economic Journal of Takasaki City University of Economics, 45(1), 15-33. Retrieved from http://www1.tcue.ac.jp/ home1/k-gakkai/ronsyuu/ronsyuukeisai/45_1/hojo.pdf

22. Hughes, C. G. (1982). The employment and economic effects of tourism reappraised. Tourism Management, 3(3), 167-176. https://doi.org/10.1016/02615177(82)90065-6

23. Ilić, I., \& Petrevska, I. (2018). Using DEA method for determining tourism efficiency of Serbia and the surrounding countries. Hotel and Tourism Management, 6(1), 73-80. Retrieved from https://www.researchgate. net/publication/326499765_Using_DEA_method_for_determining_tourism_efficiency_of_Serbia_ and_the_surrounding_countries
24. Jacint, B., \& Cantavella-Jorda, M. (2002). Tourism as a long-run economic growth factor: The Spanish case. Applied Economics, 34(7), 877-884. https://doi. org/10.1080/00036840110058923

25. Kamac1, A., \& Oğan, Y. (2014). The effects of tourism revenues on economic growth: A panel cointegration and causality analysis. International Conference on Eurasian Economies, 1-6.

26. Kumar, J., \& Hussain, K. (2014). Estimating the Economic Impact of Business Tourism: A Review of Issues and Methods. 12th APacCHRIE Conference 2014. Retrieved from https://www.researchgate. net/publication/273317642

27. Mazaraki, A., Boiko, M., Bosovska M., Vedmid, N., \& Okhrimenko, A. (2018). Formation of National Tourism System of Ukraine. Problems and Perspectives in Management, 16(1), 68-84. Retrieved from http://dx.doi.org/10.21511/ ppm.16(1).2018.07

28. Okhrimenko, A. (2017). Strategic vectors of transformational shifts in the national tourism system of Ukraine. CES Working Papers, $I X(3), 506-528$. Retrieved from http://ceswp.uaic.ro/articles/ CESWP2017_IX3_OKR.pdf

29. Pyatt, G., \& Round, J. I. (1985). Social Accounting Matrices: A Basis for Planning. The World Bank Washington, D.C., U.S.A. Retrieved from http://documents.worldbank.org/curated/ en/919371468765880931/pdf/ multi-page.pdf

30. Rasul, A., Dewana, A. A. H., \& Saed, S. M. N. (2019). Multi-model tourist forecasting: case study of Kurdistan Region of Iraq. Tourism and Travelling, 2(1), 24-34. https:// doi.org/10.21511/tt.2(1).2019.04

31. Sadler, P. G., \& Archer, B. H. (1975) The economic impact of tourism in developing countries. Annals of Tourism Research, 3(1), 15-32 https://doi.org/10.1016/01607383(75) $90015-8$

32. Saglam, Y., \& Egeli, H. A. (2018). The Nexus Between Tourism and Economic Growth. Case of Commonwealth of Independent
States. Journal of Multidisciplinary Academic Tourism, 3(2), 45-51. https://doi.org/10.31822/jomat.451676

33. Soylu, Ö. B., Çakmak, I., \& Okur, F. (2018). Economic growth and unemployment issue: Panel data analysis in Eastern European Countries. Journal of International Studies, 11(1), 93-107. https://doi.org/10.14254/20718330.2018/11-1/7

34. Soysal-Kurt, H. (2017). Measuring Tourism Efficiency of European Countries by Using Data Envelopment Analysis. European Scientific Journal, 13(7), 31-49. https://doi. org/10.19044/esj.2017.v13n10p31

35. State Statistics Service of Ukraine. (2017). Metodolohichni polozhennia iz skladannia dopomizhnoho (satelitnoho) rakhunku turyzmu v Ukraini: Nakaz vid 29.12.2017 No. 359 [Methodological provisions for compiling an auxiliary (satellite) account of tourism in Ukraine: Decree dated 29.12.2017 No. 359] (In Ukrainian). Retrieved from http://www.ukrstat.gov.ua/ norm_doc/2017/359/359_2017. htm

36. Stynes, D. J. (1997). Economic Impacts of Tourism. Illinois Bureau of Tourism, Department of Commerce. Retrieved from https://msu. edu/course/prr/840/econimpact/ pdf/ecimpvol1.pdf

37. Stynes, D. J. (1999). Approaches to estimating the economic impacts of tourism; Some examples. East Lansing, MI: Department of Park, Recreation and Tourism Resources, Michigan State University. Retrieved from https://msu.edu/ course/prr/840/econimpact/pdf/ ecimpvol2.pdf

38. The World Bank. (2019). Ukraine. Retrieved from https:// data.worldbank.org/country/ ukraine? view=chart

39. Tkachenko, T. I. (2006). Stalyi rozvytok turyzmu: teoriia, metodolohiia, realii biznesu [Sustainable tourism development: theory, methodology, business realities] (537 p.). Kyiv: Kyiv National University of Trade and Economics. Retrieved from http://tourlib.net/books_ukr/ tkachenko.htm 
40. Tkachenko, T. I., \& Boiko, M. H. (2008). Priorytety natsionalnoho ekonomichnoho rozvytku $v$ konteksti hlobalizathiinykh vyklykiv [Priorities of national economic development in the context of the globalization challenges]. In V. M. Heiets \& A. A. Mazaraki (in two parts. Part 2). Retrieved from https://www.twirpx.com/ file/564220/

41. Trebicka, B. (2016). Tourism as a multiplier effect in economy: the case of Albania. International Journal of Business and Management Invention, 5(1), 17-21. Retrieved from https://www.ijbmi. org/papers/Vol(5)1/version-2/ D050102017021.pdf

42. Van der Schyff, T., Meyer, D., \& Ferreira, L. (2019). An analysis of impact of the tourism sector as a viable response to South Africa's growth and development challenges. Journal of International Studies, 12(1), 168-183. https://doi. org/10.14254/2071-8330.2019/12$1 / 11$

43. World Tourism Organization. (2001). Tourism Satellite Account: Recommended Methodological Framework. Retrieved from https://www.e-unwto.org/doi/ pdf/10.18111/9789284404377

44. World Tourism Organization. (2010a). International Recommendations for Tourism Statistics 2008. Retrieved from https://www.e-unwto.org/doi/ book/10.18111/9789211615210

45. World Tourism Organization. (2010b). Tourism Satellite Account: Recommended Methodological Framework 2008. Retrieved from https://unstats.un.org/unsd/publication/Seriesf/SeriesF_80rev1e.pdf
46. World Tourism Organization. (2018). Yearbook of Tourism Statistics, Compendium of Tourism Statistics and data files. Retrieved from http://statistics.unwto.org

47. World Tourism Organization. (2019). International Tourism Highlights. Retrieved from https://www.e-unwto.org/doi/ pdf/10.18111/9789284421152

48. World Travel and Tourism Council. (2018). Travel \& Tourism Economic impact 2018 Ukraine. Retrieved from https://www. wttc.org/-/media/files/reports/ economic-impact-research/countries-2018/ukraine2018.pdf

49. World Travel and Tourism Council. (2019). Travel \& Tourism Economic Impact 2019 World. Retrieved from https://www.wttc. org/-/media/files/reports/economic-impact-research/regions-2019/ world2019.pdf 